\title{
The effect of fluoridation on the dental health of urban Scottish schoolchildren
}

\author{
ANTHONY S. BLINKHORN AND MAUREEN D. BROWN \\ From the Department of Preventive and Children's Dentistry, University of Edinburgh
}

DEREK ATTWOOD

From the Dental Clinic, Stranraer

MARTIN C. DOWNER

From the Scottish Home and Health Department, Edinburgh

SUMMARY A comparison was made of the dental health of children aged 4-5 and 9-10 in two Scottish towns, one with fluoridated drinking water and the other without. Striking differences were observed. A 44\% reduction in decayed, missing, and filled deciduous teeth was found in 4-5-year-olds in the fluoridated compared with the non-fluoridated town and a 50\% reduction in decayed, missing, and filled permanent teeth was recorded for the 9-10-year-olds. Larger percentage differences were found for the anterior teeth : a $65 \%$ reduction in deciduous incisors and canines, and an $81 \%$ reduction in permanent incisors and canines. Fluoridation of public water supplies in urban areas of Scotland would be a safe and effective way of dramatically improving dental health.

The 1972 survey of adult dental health in Scotland ${ }^{1}$ showed that $44 \%$ of Scottish adults aged 16 and over had lost all their natural teeth. For England and Wales the comparable figure was $37 \%$.

The dental profession is fortunate because a great deal of dental caries can be reduced safely ${ }^{2-6}$ and economically by adjusting the level of fluoride in drinking water, ${ }^{67}$ thereby enabling the profession to control the disease more easily.

However, 10 years after the successful completion of the Department of Health's $s^{8}$ demonstration of the effectiveness of fluoridation, less than $1 \%$ of the Scottish population are receiving the benefits of this important public health measure, whereas approximately $10 \%$ of the population of England and Wales consume either naturally or artificially fluoridated water.

The main reasons for the disparity are that Scotland has no areas with appreciable naturally occurring fluoride and there are at present no large artificial fluoridation schemes like those supplying the cities of Birmingham and Newcastle upon Tyne south of the border.

Dumfries and Galloway is one of the few Scottish health boards where a sizeable proportion (15\%) of the population is receiving water with an optimally adjusted level $(1 \mathrm{mg} / \mathrm{l})$ of fluoride. A small part of Stranraer was included in the first phase of the fluoridation scheme which covered a large part of the rural area of Wigtownshire. This was extended to include the whole of Stranraer and its associated rural area at the beginning of 1971 .

The present study was designed to demonstrate the likely benefits of introducing fluoridation to urban areas of Scotland by comparing the dental health of children from Stranraer, a fluoridated area, with similar children from Annan, a non-fluoridated area. Although studies of this type have been carried out in England, 910 no direct evidence of the likely benefits of fluoridation in Scotland has been available since the Kilmarnock studies in the $1960 \mathrm{~s},{ }^{8}$ which also recorded the increase in caries incidence after the cessation of the fluoridation programme.

\section{Material and methods}

The study included all children in their first and penultimate years in non-denominational state primary schools in Annan and Stranraer. The Roman Catholic schools were not included as they have large 
catchment areas. The control town Annan (population 7051) was chosen because of its similarity to Stranraer (population 9853). Both are seaport towns with a mixture of rural activities and light industry. The number of dentists serving the two towns was also comparable, five in Stranraer and four in Annan.

\section{DENTAL EXAMINATION}

Although all children in the appropriate age groups received a dental examination, only those who were lifetime residents of each town were included in the analysis.

The dental examinations were shared between two examiners (A.S.B. and D.A.) The subjects were examined under constant conditions in a mobile dental surgery that visited each school. Before examination the teeth were dried by compressed air. All surfaces of teeth were examined. Diagnosis of caries was carried out according to visual criteria and a standardised blunt sickle probe with a $0.5 \mathrm{~mm}$ diameter tip was used to confirm or reject doubtful lesions. Radiographs were not taken. Details of the criteria and method of examination are not given in this report as they have been described fully elsewhere. ${ }^{11}$

\section{EXAMINER STANDARDISATION}

Before the main survey both examiners underwent a course of training and calibration. The trainee examiners became conversant with the protocol, criteria were clarified, and photographs of diseased and healthy teeth examined. In the next stage children were inspected and the examiners conferred about the findings. Finally, independent duplicate examinations of five subjects took place and a satisfactory standard of agreement was considered to have been achieved. Replicate examinations were carried out during the study and the results are reported. Reliability coefficients (equivalent to Pearson's r) were calculated. Data for the whole mouth were subjected to two-way analysis of variance to allow the mean caries index scores to be adjusted for differences between examiners.

\section{Results}

EXAMINER STANDARDISATION

Table 1 presents the findings from replicate examinations of fourteen 4-5-year-olds and fourteen 9-10-year-olds performed independently by the two examiners during the main survey. None of the differences between mean scores was statistically significant. Interrater reliability coefficients ranged from $\mathbf{0 . 8 4}$ for mean numbers of decayed permanent teeth to 0.97 for both decayed deciduous teeth and decayed, missing, and filled deciduous teeth.

\section{STUDY POPULATION}

Table 2 shows that, of those children eligible, 262 (95\%) of the 4-5-year-olds and $346(96 \%)$ of the 9-10-year-olds were examined. Of these, lifetime residents constituted $230(88 \%)$ of the 4-5-year-olds and $288(83 \%)$ of the $9-10$-year-olds. The results reported refer to these lifetime residents. Within each town the children of each group were divided equally between the two examiners.

\section{MAIN SURVEY}

The findings for dental caries in both age groups in the two towns are compared in Table 3 . It should be noted that adjusted means are presented for the whole mouth index scores to allow for the influence of having two examiners. The very small differences between the adjusted and unadjusted means confirm the high level of diagnostic agreement between the examiners. The 4-5-year-olds in the fluoridated town, Stranraer, had a mean number of decayed, missing, and filled deciduous teeth of 2.47 compared with 4.41 for Annan, the non-fluoridated town-a $44 \%$ reduction. A higher percentage reduction $(60 \%)$ was observed in the mean numbers of deciduous

Table 1 Mean scores obtained by two examiners at replicate examinations of fourteen 4-5-year-olds and fourteen 9-10year-olds

\begin{tabular}{|c|c|c|c|c|}
\hline & $\begin{array}{l}\text { Examiner I } \\
\text { mean (SD) }\end{array}$ & $\begin{array}{l}\text { Examiner } 2 \\
\text { mean (SD) }\end{array}$ & $\begin{array}{l}\text { Difference } \\
\text { mean }(S E)\end{array}$ & $\begin{array}{l}\text { Interrater } \\
\text { reliability } \\
\text { coefficient } \% c c\end{array}$ \\
\hline$\underset{d m f t}{d t}$ & $\begin{array}{ll}1.36 & (2.13) \\
1.79 & (2.42)\end{array}$ & $\begin{array}{ll}1 \cdot 50 & (2 \cdot 24) \\
2.00 & (2 \cdot 54)\end{array}$ & $\begin{array}{ll}0.14 & (0.14) \\
0.21 & (0.16)\end{array}$ & $\begin{array}{l}0.97 \\
0.97\end{array}$ \\
\hline $\begin{array}{l}\text { 9-10-YEAR-OLDS } \\
\text { DT } \\
\text { DMFT }\end{array}$ & $\begin{array}{ll}1.14 & (1 \cdot 10) \\
2.50 & (1.70)\end{array}$ & $\begin{array}{ll}1.29 & (1.20) \\
2.57 & (1.40)\end{array}$ & $\begin{array}{ll}0.15 & (0.18) \\
0.07 & (0.17)\end{array}$ & $\begin{array}{l}0.84 \\
0.94\end{array}$ \\
\hline
\end{tabular}

$\mathrm{dt}=$ decayed deciduous teeth

dmft $=$ decayed, missing, and filled deciduous teeth

DT $=$ decayed permanent teeth

DMFT = decayed, missing, and filled permanent teeth 
Table 2 Study population

\begin{tabular}{lllllll}
\hline & \multicolumn{3}{l}{$\begin{array}{l}\text { Total population } \\
\text { Age groups } \\
\text { (years) }\end{array}$} & No. examined & \multicolumn{2}{l}{$\begin{array}{l}\text { No. of lifetime } \\
\text { residents }\end{array}$} \\
\cline { 2 - 7 } & $4-5$ & $9-10$ & $4-5$ & $9-10$ & $4-5$ & $9-10$ \\
\hline $\begin{array}{l}\text { Stranraer } \\
\text { (fluoridated) }\end{array}$ & 158 & 190 & 151 & 183 & 129 & 147 \\
$\begin{array}{l}\text { Annan } \\
\text { (non-fluoridated) }\end{array}$ & 117 & 170 & 111 & 163 & 101 & 141 \\
\begin{tabular}{l} 
Total \\
\hline
\end{tabular} & 275 & 360 & 262 & 346 & 230 & 288 \\
\hline
\end{tabular}

teeth with untreated decay. For the 10 -year-olds, the mean number of decayed, missing, and filled permanent teeth was 1.66 in Stranraer compared with 3.35 in Annan-a 50\% reduction. The difference in the mean numbers of permanent teeth with untreated decay was considerable, amounting to over $70 \%$.

The numbers and percentages of children in the two age groups from Stranraer and Annan who were found to be free of untreated caries and who had no caries are presented in Table 4. Twenty-two per cent of the 4-5-year-olds in Annan were free from caries, and only $10 \%$ of the 9-10-year-olds were free from active caries attack. The differences in Stranraer were striking : over half $(53 \%)$ of the 4-5-year-olds were free from caries. This improvement was even more marked in the older age group, in which $77 \%$ were free from caries.

Forty-three per cent of the children entering primary school in fluoridated Stranraer showed no evidence of having experienced any decay at all, compared with only $16 \%$ of primary school entrants in non-fluoridated Annan. Similar findings were recorded in the older age group. Table 4 shows that over a third (35\%) of the 9-10-year-olds in Stranraer had no evidence of experience of decay in their permanent teeth, compared with only $10 \%$ of those in Annan.

Table 5 shows a comparison of the caries in anterior teeth. Here the percentage differences between the fluoridated and the non-fluoridated town were even greater. The reduction in the mean numbers of decayed deciduous incisors and canines was $65 \%$, while the equivalent reduction in decayed, missing, and filled deciduous teeth was also $65 \%$. Higher percentage differences were recorded for the 9-10-year-olds, with a reduction of $81 \%$ in the mean number of decayed, missing, and filled permanent teeth (anterior) and a difference of $85 \%$ for anterior permanent teeth with untreated decay. All the differences presented in Table 5 were statistically significant.

\section{Discussion}

This comparison of dental health and need for treatment among children from the fluoridated town of Stranraer and the non-fluoridated town of Annan supports the findings of many previous studies. The decay among new school entrants to primary school was 44\% lower in Stranraer than in Annan. The benefits of fluoridation were also reflected in the older age group, where a 50\% difference in decayed, missing, and filled permanent teeth was recorded.

As has been demonstrated in previous studies, the anterior teeth gained particular benefit from fluoridation; differences of $65 \%$ for the younger and $81 \%$ for the older group were found. Untreated, decayed anterior teeth can spoil a young person's appearance and it is clear that children in Stranraer had cosmetic advantages compared with children in Annan because of the notable reduction in caries in the front teeth.

Table 4 Dental health of children in a fluoridated and a non-fluoridated community

\begin{tabular}{|c|c|c|c|c|}
\hline & \multicolumn{2}{|c|}{$\begin{array}{l}\text { Fluoridated } \\
\text { No. } \quad \text { (\%) }\end{array}$} & \multicolumn{2}{|c|}{$\begin{array}{l}\text { Non-fluoridated } \\
\text { No. (\%) }\end{array}$} \\
\hline 4-5-YEAR-OLDS & \multicolumn{2}{|c|}{$(\mathrm{n}=129)$} & \multicolumn{2}{|c|}{$(n=101)$} \\
\hline $\begin{array}{l}\text { No untreated caries } \\
(\mathrm{dt}=0)\end{array}$ & 69 & (53) & 22 & (22) \\
\hline $\begin{array}{l}\text { No experience of caries } \\
(\mathrm{dmft}=0)\end{array}$ & 55 & (43) & 16 & (16) \\
\hline 9-10-YEAR-OLDS & \multicolumn{2}{|c|}{$(n=147)$} & \multicolumn{2}{|c|}{$(n=141)$} \\
\hline $\begin{array}{l}\text { No untreated caries } \\
(D T=0)\end{array}$ & 113 & (77) & 51 & (36) \\
\hline $\begin{array}{l}\text { No experience of caries } \\
(\mathrm{DMFT})=0)\end{array}$ & 51 & (35) & 14 & (10) \\
\hline
\end{tabular}

Table 3 Caries in a fluoridated and a non-fluoridated community

\begin{tabular}{|c|c|c|c|c|c|c|c|c|c|}
\hline & \multicolumn{3}{|c|}{ Fluoridated } & \multicolumn{3}{|c|}{ Non-fluoridated } & \multicolumn{3}{|c|}{ Difference } \\
\hline & Mean & $(S D)$ & $\begin{array}{l}\text { Adjusted } \\
\text { mean }\end{array}$ & Mean & $(S D)$ & $\begin{array}{l}\text { Adjusted } \\
\text { mean }\end{array}$ & Mean & $\boldsymbol{F}$ & $\begin{array}{l}\text { Percentage } \\
\text { difference }\end{array}$ \\
\hline $\begin{array}{c}\text { 4-5-YEAR-OLDS } \\
\mathrm{dt} \\
\mathrm{dmft}\end{array}$ & $\begin{array}{l}1 \cdot 36 \\
2 \cdot 48\end{array}$ & $\begin{array}{l}(n=129) \\
(2 \cdot 08) \\
(3 \cdot 16)\end{array}$ & $\begin{array}{l}1 \cdot 34 \\
2 \cdot 47\end{array}$ & $\begin{array}{l}3 \cdot 32 \\
4 \cdot 39\end{array}$ & $\begin{array}{l}(n=101) \\
(3 \cdot 38) \\
(4 \cdot 04)\end{array}$ & $\begin{array}{l}3 \cdot 34 \\
4 \cdot 41\end{array}$ & $\begin{array}{l}2.00 \\
1.94\end{array}$ & $\begin{array}{l}31 \cdot 5^{*} \\
17 \cdot 0^{*}\end{array}$ & $\begin{array}{l}60 \\
44\end{array}$ \\
\hline $\begin{array}{l}\text { 9-10-YEAR-OLDS } \\
\text { DT } \\
\text { DMFT }\end{array}$ & $\begin{array}{l}0.35 \\
1.66\end{array}$ & $\begin{array}{l}(n=147) \\
(0 \cdot 74) \\
(1 \cdot 63)\end{array}$ & $\begin{array}{l}0.35 \\
1.66\end{array}$ & $\begin{array}{l}1 \cdot 35 \\
3 \cdot 35\end{array}$ & $\begin{array}{l}(n=141) \\
(1 \cdot 50) \\
(2 \cdot 32)\end{array}$ & $\begin{array}{l}1 \cdot 36 \\
3 \cdot 35\end{array}$ & $\begin{array}{l}1.01 \\
1.69\end{array}$ & $\begin{array}{l}53 \cdot 1^{*} \\
50.7^{*}\end{array}$ & $\begin{array}{l}74 \\
50\end{array}$ \\
\hline
\end{tabular}

p $<0.01$. 
Table 5 Caries of anterior teeth in fluoridated and non-fluoridated communities

\begin{tabular}{|c|c|c|c|c|c|c|}
\hline & $\begin{array}{l}\text { Fluoridated } \\
\text { Mean }\end{array}$ & (SD) & $\begin{array}{l}\text { Non-fluoridated } \\
\text { Mean }\end{array}$ & $\begin{array}{l}\text { Difference } \\
\text { Mean }\end{array}$ & (SE) & $\begin{array}{l}\text { Percentage } \\
\text { difference }\end{array}$ \\
\hline $\begin{array}{c}\text { 4-5-year-olds } \\
\mathrm{dt} \\
\mathrm{dmft}\end{array}$ & $\begin{array}{l}0.27^{(n=12} \\
0.30\end{array}$ & $\begin{array}{l}\text { 9) } \\
(0.91) \\
(1 \cdot 10)\end{array}$ & $\begin{array}{ll} & (\mathrm{n}=101) \\
0.78 & (1.96) \\
0.86 & (2.02)\end{array}$ & $\begin{array}{l}0.51^{\circ} \\
0.56^{\circ}\end{array}$ & $\begin{array}{l}(0.19) \\
(0.21)\end{array}$ & $\begin{array}{l}65 \\
65\end{array}$ \\
\hline $\begin{array}{l}\text { 9-10-YEAR-OLDS } \\
\text { DT } \\
\text { DMFT }\end{array}$ & $\begin{array}{l}0.04^{(n=14} \\
0 \cdot 10\end{array}$ & $\begin{array}{l}7) \\
(0 \cdot 23) \\
(0.46)\end{array}$ & \begin{tabular}{ll} 
& \multicolumn{2}{c}{$(n=141)$} \\
$0.26^{(n=14)}$ & $(0.78)$ \\
0.52 & $(1.50)$
\end{tabular} & $\begin{array}{l}0.22^{*} \\
0.42^{*}\end{array}$ & $\begin{array}{l}(0.07) \\
(0.13)\end{array}$ & $\begin{array}{l}85 \\
81\end{array}$ \\
\hline
\end{tabular}

$\bullet p<0.01$.

Rugg-Gunn et al ${ }^{12}$ have reported that fluoridation greatly reduces episodes of toothache and attendances for emergency treatment. This study supports those findings, as $53 \%$ of the 4-5-year-olds and $77 \%$ of the $9-10$-year-olds in fluoridated Stranraer had no evidence of untreated active carious lesions. This compares with corresponding proportions of only $22 \%$ and $36 \%$ for non-fluoridated Annan.

The comprehensive report of the Royal College of Physicians in $1976^{2}$ provided authoritative support for the safety of fluoridation. Recently other official commissions of inquiry have extensively reviewed current evidence and confirmed this view. ${ }^{3-5}$ The conclusions of the Governor's Commission on Fluoridation for the State of Minnesota ${ }^{5}$ reflect current informed opinion on the safety of water fluoridation. The commission concluded: 'With regard to potential adverse health effects of fluoridation, the commission finds that the claims that fluoride is allergenic, mutagenic or carcinogenic are not supported by the preponderence of available scientific data'.

The government of the United Kingdom has reaffirmed its support of fluoridation in a recent statement to the House of Commons by the Under-Secretary of State for Health and Social Security that 'extensive trials throughout the world have shown that fluoridation safely and effectively reduces the prevalence of dental caries'.18

All the Scottish area health boards have recommended that their corresponding regional councils should adjust the level of fluoride in the drinking water. The results from this study have shown that if this advice was implemented the dental health of Scottish children would be dramatically improved. Fluoridation is particularly appropriate for Scotland as the majority of the population live in a small number of conurbations.

We thank the children, schools, and head teachers who co-operated in the study, and Mrs. P. M. Whelan for useful background information. We also thank Mr. A. R. Wales, the Chief Administrative Dental
Officer for Dumfries and Galloway, and Professor P. Sutcliffe of Edinburgh University. The mobile examining van was kindly loaned by Greater Glasgow Health Board through the good offices of Dr. K. W. Stephen. The study was funded by the Scottish Health Education Group.

Reprints from Dr. A. S. Blinkhorn, 17 Teviot Place, Edinburgh EH1 2QZ.

\section{References}

'Todd JE, Whitworth A. Adult dental health in Scotland 1972. London: HMSO, 1974.

${ }^{2}$ Royal College of Physicians. Fluoride, teeth and health. Tunbridge Wells; Pitman Medical, 1976.

${ }^{3}$ National Health and Medical Research Council. Submission to the Committee of Inquiry into the Fluoridation of Victorian Water Supplies. Mimeo. Melbourne: NHMRC, 1979.

- Office of the Governor of Michigan. Report of the Governor's Task Force on Fluoride. Mimeo. Lansing. Michigan: Office of the Governor, 1979.

3 Anders MW, Dorsen P, Steenson JD. Report of the Governor's Commission on Fluoridation. Mimeo. Minneapolis, Minnesota: Office of the Governor, 1979.

- Dirks OB. The assessment of fluoridation as a preventive measure in relation to dental caries. Br Dent J 1963; 114: 211-6.

${ }^{7}$ Ast DB, Smith DJ, Wachs B, Cantwell KT. Newburgh-Kingston caries-fluorine study XIV. J Am Dent Assoc 1956; 52: 629-34.

- Department of Health and Social Security. The fluoridation studies in the United Kingdom and the results achieved after eleven years. London: HMSO, 1969.

- Murray JJ. Caries experience of fifteen-year-old children from fluoride and non-fluoride communities. Br Dent $J$ 1969; 127: 128-31.

${ }^{10}$ Whittle JG, Downer MC. Dental health and treatment needs of Birmingham and Salford school children. $\mathrm{Br}$ Dent J 1979; 147: 67-71.

"Downer MC, Teagle FA, Whittle JG. Field testing of an information system for planning and evaluating dental services. Community Dent Oral Epidemiol 1979; 7: 11-16.

${ }^{12}$ Rugg-Gunn AJ, Carmichael CL, French AD, Furness JA. Fluoridation in Newcastle and Northumberland. $\mathrm{Br}$ Dent J 1977; 142: 395-402.

${ }^{13}$ Hansard, House of Commons, 6 March 1980, col 800. 